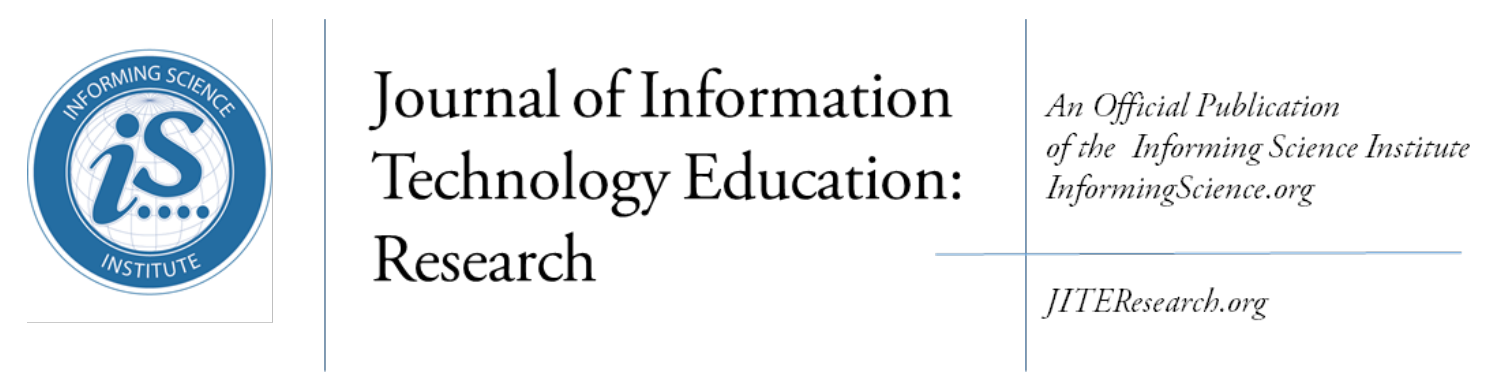

Volume 16, 2017

\title{
Preparing Teacher Candidates For VIRTUAL FIELD PLACEMENTS VIA AN EXPOSURE TO K-12 ONLINE TEACHING
}

Tian Luo*

Laura Hibbard

Teresa Franklin

David Richard Moore

* Corresponding author
Old Dominion University, Norfolk, VA, USA

Ohio University, Athens, OH, USA

Ohio University, Athens, OH, USA

Ohio University, Athens, OH, USA tluo@odu.edu

hibbardl@ohio.edu

franklit@ohio.edu

moored3@ohio.edu

\begin{abstract}
Aim/Purpose The goal of this project was to determine what effects exposure to online K-12 teaching and learning activities had on teacher candidates' perceptions of K-12 online learning, how the exposure allowed teacher candidates to reach greater understanding of online pedagogy, and what effect such exposure had on teacher candidates' aspirations to complete virtual field experiences.

Background

With an increasing number of K-12 students learning online within full-time online schools and in blended learning environments, universities must prepare future educators to teach in virtual environments including clinical practice. Before engaging in online field placement, preservice teachers must be oriented to online K-12 teaching and learning.

Methodology

Using a design-based, mixed-method research methodology, this study drew samples from four sections of a hybrid technology integration course. Preservice teachers' papers detailing their perceptions, focus groups, and surveys were used to gauge changes in perceptions of online learning after participating in online teaching and learning activities.

Contribution The study demonstrated that an exposure to online K-12 classrooms stimulated preservice teachers' interest in online teaching as they began to feel that online education could be equivalent to traditional education.

Findings Students' perceptions positively improved the equivalency of online learning to traditional schooling, the possibility of positive relationships between teachers and students, and the ability to create interactive learning. Students also reported being more knowledgeable and showed increased interest in participating in virtual field experiences.
\end{abstract}

Accepted by Editor Louise Spiteri | Received: November 8, 2016 | Revised: December 12, 2016 | Accepted: December 15, 2016.

Cite as: Luo, T., Hibbard, L., Franklin, T., \& Moore, D. R. (2017). Preparing teacher candidates for virtual field placements via an exposure to K-12 online teaching. Journal of Information Technology Education: Research, 16, 1-14. Retrieved from http://www.informingscience.org/Publications/3626

(CC BY-NC 4.0) This article is licensed it to you under a Creative Commons Attribution-NonCommercial 4.0 International License. When you copy and redistribute this paper in full or in part, you need to provide proper attribution to it to ensure that others can later locate this work (and to ensure that others do not accuse you of plagiarism). You may (and we encourage you to) adapt, remix, transform, and build upon the material for any non-commercial purposes. This license does not permit you to use this material for commercial purposes. 
Future Research Future research may continue to examine if the exposure course, combined with a short-term clinical experiences and long-term online apprenticeships may serve to prepare graduates with the skills necessary to teach in classrooms of the future.

Keywords online teaching, online learning, preservice teachers, online schools, virtual schools

\section{INTRODUCTION}

Online education, whether as full-time programs or integrated blended programs, is an increasing phenomenon in K-12 school systems (Pourreau, 2015). Teachers are being asked to educate in online or blended learning environments, yet few have had opportunities to develop appropriate skill sets in this arena (Wilkens et al., 2014). A necessary component of teacher education is clinical practice, or field experiences: a time for preservice teachers, who are teacher candidates being trained or supervised in preparation of a teaching role in K-12 school environments, to place theory into practice as students apprentice in classrooms with mentor teachers (Council for the Accreditation of Educator Preparation, 2015; Pourreau, 2015). To develop skills in online pedagogy, teacher education programs need to expand their current practices and focus on preparing preservice teachers to teach online (Kennedy \& Archambault, 2012a). Online teaching skills are not only necessary to meet the needs of full-time online schools but to build a teaching corps ready to infuse traditional schools with integrated online offerings (Davis \& Roblyer, 2005; DeNisco, 2013). This hybridization of K-12 is a natural outgrowth of technological advancement and increasing demands of society. To take advantage of these opportunities requires, at a minimum, teachers who have experienced teaching or learning in an online environment (Kennedy \& Archambault, 2012a).

What often is absent from previous studies on teacher education programs is an introduction to online learning so that preservice teachers may enter virtual field experiences with a solid background of K-12 online learning. This study was an attempt to fill that knowledge gap by exploring the effects of various learning activities designed to orient preservice teachers to online K-12 teaching and examining how various learning activities may have facilitated preservice teachers' perception change of K-12 online teaching, which is integral to preparing them for virtual field placements. This paper serves to discuss the preparation needed by preservice teachers prior to participating in clinical experiences in hopes that perceptions may be vetted, misconceptions may be remedied, online K-12 pedagogical knowledge may be gained, and students' aspirations to apprentice in virtual environments is heightened.

\section{CONCEPTUAL FRAMEWORK}

Situated cognition learning theory was chosen as a conceptual framework to ground the research. Situated learning theories place a high emphasis on the social and physical contexts in which learning occurs and how learning occurs are inherently interwoven. In order to have a full grasp of concepts, learners must learn from where learning takes place and apply these learned concepts in the social and physical environments in which they are situated (Brown, Collins, \& Duguid, 1989). To intentionally situate learning in a certain context is necessary and critical in that the process can be modeled and transferred to other activities in which meanings are negotiated and therefore intrinsically constructed by the learners. The social and situated component of learning becomes a critical element for learning to occur. The design of the various learning activities in this study followed a situated learning approach by allowing preservice teachers to observe the teaching environment where online learning takes place in the context of a virtual K-12 school that the university partnered with.

In order to better prepare preservice teachers for their clinical experience of online teaching, they need exposure to online learning activities at the K-12 level when they are in college. In this study, preservice teachers received a multitude of video recordings across various disciplines where they can observe how online teachers actually teach a class in a virtual classroom and how they interact with 
students who are at a distance from one another. Additionally, in-service online teachers received invitations to come into the classroom to share their own experiences being an online teacher. Interposed between these activities, preservice teachers reflected on their learning experiences by interacting among themselves as well as with the invited online teachers in a large lecture room. Following situated learning theory, these activities place a crucial emphasis on the social environment and mechanism in which individual preservice teachers situate themselves in an online K-12 teaching environment as they watched from the videos and collectively and collaboratively learn from the guest speakers and from themselves. Through this mechanism, preservice teachers are able to formulate their own perception of online K-12 learning and teaching and deepen their understanding of what it takes to be a quality online teacher.

\section{K-12 ONLINE LEARNING}

Throughout the past century, many students have had the opportunity to learn from a distance. From correspondence courses relying primarily on the postal system to educational radio and television, students and teachers have explored the notion of learning in geographically distinct locations. In the mid 1990s, students and teachers began leveraging the power of personal computers and the Internet and online K-12 schooling was born (Clark \& Barbour, 2015). Online K-12 schooling flourished throughout the next two decades, and during the 2013-2014 school year an estimated 315,000 U.S. students accessed their education through full-time online schools (Watson, Pape, Murin, Gemin, \& Vashaw, 2014). This same year, state virtual schools provided an additional 740,000 online K-12 course enrollments to students seeking supplemental courses (Watson et al., 2014).

The dichotomy between full-time online schools and brick-and-mortar schools that has persisted over the past twenty years is beginning to become blurred, as traditional K-12 schools have implemented blended learning practices in an attempt to personalize learning (Patrick \& Sturgis, 2015). Blended learning refers to a formal education program that utilizes both face-to-face teaching as well as online learning. The two segments are related: what students learn online integrates with what is being taught in person, and students have some control over the time and place of learning, their pace of learning, or the path of learning (Powell, Rabbitt, \& Kennedy, 2014). With the exception of very small districts (up to about 2,500 students), the majority of U.S. public school districts (roughly 25,000 students and higher), are embracing technical resources for content delivery, for managing learning, and for meeting technology standards (Watson et al., 2014).

With students learning online, either full-time or in blended environments, teachers must gain proficiency in online pedagogy. Universities acknowledging these changes need to prepare tomorrow's $\mathrm{K}$ 12 teacher workforce appropriately. Unfortunately, according to a 2012 national survey, only $1.3 \%$ of university teacher preparation programs offered virtual field experiences to equip students to gain expertise in digital learning (Kennedy \& Archambault, 2012b). Traditional face-to-face education benefits from teaching candidates having twelve years of maturation in the traditional school environment. In a traditional model, the teacher is a role model for the future teacher. Such role modeling is absent with regard to the online environment; it is simply too new (Archambault, 2011). Only very few examples of teacher preparation programs for online teaching exist at the moment (Barbour, Siko, Gross, \& Waddell, 2013). Research indicates that many teacher training programs still use traditional methods (Kennedy \& Archambault, 2012a, 2012b).

Although the trend to hybridization of traditional and online education is clear, the path to pedagogical mastery is obscure, as only eight states (Georgia, Idaho, Michigan, Louisiana, South Carolina, Utah, and Vermont) have policies in place delineating online teaching standards (Archambault, DeBruler, \& Freidhoff, 2014). Researchers stressed the importance of understanding the alternative online teaching methods as necessities to better prepare pre-service teachers in online environments (Archambault et al., 2014; Brecheisen, 2015). Continued research is much needed to understand how teacher education initiatives can prepare all teachers with adequate training on how to design, deliver, and support K-12 online teaching (Barbour et al., 2013). 
In the context of this study, preservice teachers were exposed to a hybrid format of learning where both face-to-face lecturing and online synchronous and asynchronous instructional activities occur in one course. The research team implemented a series of activities that blend traditional instruction with online instruction aiming at changing any unwarranted preconceptions regarding online teaching and learning and further preparing preservice teachers to possibly participate in clinical experiences who have aspirations to teach online.

The following questions guided the learning activities, data collection, and analysis.

1. What effect did activities orienting preservice teachers to online $\mathrm{K}-12$ teaching have on preservice teachers' perceptions of K-12 online teaching?

2. How did exposure to exemplar online K-12 synchronous teaching sessions and guest speakers allow preservice teachers to reach a greater understanding of K-12 online learning?

3. How, if at all, did the online K-12 teaching activities change preservice teachers' aspirations of teaching in an online or blended environment?

\section{METHODOLOGY}

\section{RESEARCH DESIGN AND CONTEXT}

This study employed a design-based, mixed-method research methodology, which is a pragmatic research approach that involves the planning, designing, implementation, and evaluation of a teaching intervention aiming at delivering outcomes constructed in real-world contexts (Anderson \& Shattuck, 2012; Creswell \& Clark, 2007). This design-based research approach is of critical value to improving curriculum development, renovating instructional strategies, and reassessing student learning. The goal of incorporating online K-12 pedagogy through a partnership with a virtual K-12 school was to improve the course design and prepare teacher candidates for virtual field placements.

In this study, an exposure to online teaching was implemented in a course required of all education majors called Technology Applications in Education, a hybrid technology integration course where preservice teachers learn to apply a wide variety of technology applications in teaching and learning settings. The class met face-to-face three times per semester with the remaining content delivered online. The course was taught in both Fall and Spring semesters by two different instructors in each semester. The four implementations provided a broad representation of participants. To infuse online K-12 pedagogy into the curriculum, a partnership was forged with a full-time online K-12 school. This was an initial foray into the world of online education for the teacher preparation program, the partnering online school, the preservice teachers, and the course designers. The partnership provided a time for preservice teachers and faculty to explore their preconceptions of online teaching and learning as well as to be exposed to current practices in $\mathrm{K}-12$ online education.

\section{PARTICIPANTS}

A total of four sections of the course was held during both the fall and spring semesters during the 2013-2014 school year. Upon the approval of the university's IRB (approval \#13E224), 171 preservice teachers from the course were invited to participate in the study; 141 preservice teachers agreed to participate $(70.5 \%)$ and therefore became participants of the study. Detailed descriptions of the learning activities as well as the data collection methods are presented in the following sections.

\section{DATA COLLECTION}

The research implementation took place in two continuous fifteen-week semesters across four class sessions. Each fifteen-week semester began with two activities: A pre-class perception paper and a survey. The pre-class perception paper assignment asked participants to describe their prior knowledge and feelings surrounding K-12 online teaching and learning and to describe their level of interest for virtual field experiences. Open-ended prompts encouraged participants to explore their 
thoughts on the (a) benefits and drawbacks of online education, (b) ideal ages to learn online, (c) the equivalency of online learning compared to learning in a traditional manner, (d) teacher/student relationships in an online class, (e) managing discipline in an online class, (f) the ability to individualize learning in online environments, and (g) student collaboration in an online classroom. Eliciting early reflections allowed the researchers to uncover misconceptions to be addressed and reflected upon as the course progressed (Compton, Davis, \& Mackey, 2009).

Participants began the semester by answering a demographic survey via Qualtrics, which gathered data on the participants' year of study, major area of study (early childhood/elementary, middle, high school), prior online learning experiences (including blended learning), and interest in virtual teaching field experiences.

Approximately one-third of the way through the semester, participants were asked to watch video recordings of three online K-12 synchronous teaching sessions provided by the partnering K-12 virtual school. Though they were encouraged to watch all three, participants were required to select at least one of three videos, respectively, Fifth Grade Language Arts that lasted 30 minutes, Middle School Language Arts that lasted 54 minutes, or High School Algebra that lasted 55 minutes. The goal was to select one video that most closely approximated the grade of their teaching aspirations. Elluminate Live! ${ }^{\circledR}$ software was used by the partnering online K-12 school and these videos were actual teaching sessions recorded earlier by the school.

At about the mid-term point to the end of the semester, five current online teachers from the online K-12 partnering school provided a presentation during the face-to-face class sessions as guest speakers. Guest speakers discussed why and how they started their online teaching, depicted what a typical day working in an online K-12 school looked, and shared the strengths and struggles they had as an online teacher, as well as answered many questions from preservice teachers. Each guest talk session lasted approximately an hour. To facilitate audience questions, todaysmeet.com was utilized as a rolling feed of questions that the presenters addressed periodically.

Approximately two-thirds of the way through the semester, a second round of videos of synchronous teaching sessions was presented to the participants. Both cohorts of participants viewed the second round of videos (Fourth Grade Language Arts; Ninth Grade Math, and High School Spanish). The final required learning activity was a post-class perception reflection. Similar to the pre-class perception paper utilized at the beginning of the semesters, the post-class perception papers were used to gauge changes in the participants' perceptions of online teaching, if any. The questions in the post-class perception paper were almost identical to the pre-class paper with only a few items that were worded differently. Both pre- and post-class perception papers were part of the participants' course assignment.

Focus groups were optional activities in which the participants could debrief the online teaching and learning components of the class. At the conclusion of the semesters, a total of 31 preservice teachers participated in the focus groups $(22 \%)$. The focus groups solicited feedback on the videos, the guest speakers, online teaching, virtual teaching aspirations, and the class experience as a whole.

\section{DATA ANALYSIS}

Data sources consist of the pre-class surveys, pre- and post-perception papers, and focus groups. As research implementation was conducted across four sessions with the same population of preservice teachers in a teacher education program, and because the online teaching activities remained constant, data from both semesters were combined for analysis.

Quantitative analysis encompassed a descriptive statistical analysis of the survey data, as well as a $t$ test analysis of numerical variables coded from the pre- and post- perception papers. Survey data were exported from Qualtrics into SPSS, so that the fall data set and spring data set could be combined. Descriptive statistics were generated on the following demographics: student's instructor, year in teacher preparation program, major area of study, prior online learning experiences in both K-12 
schools and universities, and participants' interests in teaching virtually as part of their teacher preparation field experiences.

Table 1. A table showing a conversion from qualitative questions to quantitative variables

\begin{tabular}{|c|c|c|}
\hline Question prompts* & Variables & Values \\
\hline $\begin{array}{l}\text { Do you think there is an ideal } \\
\text { age/grade for students to begin to } \\
\text { learn online? }\end{array}$ & $\begin{array}{l}\text { Choice of field } \\
\text { experience }\end{array}$ & $\begin{array}{l}1=\text { face-to-face } \\
2=\text { "either or" } \\
3=\text { virtual }\end{array}$ \\
\hline $\begin{array}{l}\text { Do you think online learning is } \\
\text { equivalent to a face-to-face teaching } \\
\text { and learning? }\end{array}$ & $\begin{array}{l}\text { Ideal age of } \\
\text { learning online }\end{array}$ & $\begin{array}{l}1=\mathrm{K}-5 \text { (elementary) } \\
2=6-8 \text { (middle school) } \\
3=9-12 \text { (high school) } \\
4=\text { college }\end{array}$ \\
\hline $\begin{array}{l}\text { What do you believe impacts the } \\
\text { quality of online teaching/learning } \\
\text { are? }\end{array}$ & $\begin{array}{l}\text { Equivalency of } \\
\text { learning online } \\
\text { versus face-to- } \\
\text { face }\end{array}$ & $\begin{array}{l}1=\text { online is equivalent to face-to- } \\
\text { face } \\
2=\text { unsure/maybe } \\
3=\text { online is not as good }\end{array}$ \\
\hline $\begin{array}{l}\text { Do you believe teachers and stu- } \\
\text { dents can build a positive relation- } \\
\text { ship if they never meet face-to-face? }\end{array}$ & $\begin{array}{l}\text { Developing posi- } \\
\text { tive teacher- } \\
\text { student relation- } \\
\text { ships }\end{array}$ & $\begin{array}{l}1=\text { online is as good as face-to-face } \\
2=\text { unsure } / \text { maybe } \\
3=\text { online is not as good }\end{array}$ \\
\hline $\begin{array}{l}\text { Do you believe it is easier to manage } \\
\text { discipline in an online classroom } \\
\text { than a face-to-face classroom? }\end{array}$ & $\begin{array}{l}\text { Managing disci- } \\
\text { pline }\end{array}$ & $\begin{array}{l}1=\text { easier than face-to-face } \\
2=\text { as same face-to-face } \\
3=\text { harder than face-to-face }\end{array}$ \\
\hline $\begin{array}{l}\text { Do you believe that individualized } \\
\text { education will be easier or more dif- } \\
\text { ficult in a virtual classroom envi- } \\
\text { ronment? }\end{array}$ & $\begin{array}{l}\text { Individualized } \\
\text { learning }\end{array}$ & $\begin{array}{l}1=\text { online is as good as face-to-face } \\
2=\text { unsure } / \text { maybe } \\
3=\text { online is not as good }\end{array}$ \\
\hline $\begin{array}{l}\text { Can an online class foster interactive } \\
\text { learning and a student-centered } \\
\text { classroom? }\end{array}$ & $\begin{array}{l}\text { Interactive learn- } \\
\text { ing }\end{array}$ & $\begin{array}{l}1=\text { online is as good as face-to-face } \\
2=\text { unsure } / \text { maybe } \\
3=\text { online is not as good }\end{array}$ \\
\hline
\end{tabular}

*Note: The question prompts were shortened to fit the presentation of the table; it was not word-forword verbatim as shown in the perception paper guidelines

The researchers randomly selected approximately $23 \%$ of participants from each of the four class sessions, resulting in a total of 33 out of all 141 participants' papers being selected. All 33 participants arose from each of the four class sessions taught by a different instructor, which represented the majority of students in the study. Each participant's answers to the seven open ended perception questions were extracted from the perception papers and coded quantitatively and then converted to ordinal variables with numerical values, including (a) participants' choice of prospective field experience, (b) the ideal age of students to learn online, (c) the equivalency of learning online versus faceto-face, (d) developing positive teacher-student relationships, (e) managing discipline in classroom, (f) individualized learning, and (g) interactive learning (See Table 1). The researchers coded participants' both pre- and post-perception papers and pulled all coded data into SPSS in order to conduct a paired $t$-test. The $t$-test was used to examine any perception change occurring in the post-class stage.

Qualitative analysis included a systematic line-by-line review process (Corbin \& Strauss, 2008) with the perception papers and the focus group transcripts. Researchers began coding the perception papers using themes in the question prompts as a priori codes (Stemler, 2001) and counted the codes 
based on frequency of responses. An open-coding approach was also used to extract common themes that emerged from participants' answers, especially on the responses regarding benefits and drawbacks of online learning. (Saldaña, 2013). Discrepancies were discussed and codes were revised until consensus was achieved.

Focus group sessions were transcribed and open coding techniques were used to code responses. Two separate researchers were involved with hosting, transcribing, and interpreting the focus group results. The review of the data consisted of organization, search for patterns, simplified categorization, and synthesis of data to develop themes through the exploration of the phenomena (Denzin \& Lincoln, 2008). The inductive codes that emerged, along with the findings, are described in the following sections (Saldaña, 2013). The disagreement among coders was later resolved through discussion. Table 2 shows all data types, sources, and analysis methods.

All research data (See Table 2) in this study collected across perception surveys, papers, and focus groups were triangulated to verify and confirm the meaning and therefore enhance the validity of the study (Patton, 2002). Different analytical methods and approaches were used to analyze the various data sources independent of other data sources, which entails descriptive analysis, statistical inferential analysis, as well as inductive and open coding approaches to qualitative data.

Table 2. A Table showing all data types, sources, and analysis methods in the study

\begin{tabular}{lll}
\hline Data Type & Data Sources & Analysis Methods \\
\hline Quantitative & Pre-class survey $(\mathrm{N}=141)$ & Descriptive statistical analysis \\
\hline Qualitative & Pre- and post-perception papers & Coded and converting to numerical \\
& $(\mathrm{N}=34)$ & variables \\
& Paired t-test \\
\cline { 2 - 3 } & Pre- and post-perception papers & A priori coding \\
& $(\mathrm{N}=34)$ & Open-coding \\
\cline { 2 - 3 } & Focus groups $(\mathrm{N}=31)$ & Open-coding \\
\hline
\end{tabular}

\section{FINDINGS}

\section{SURVEY FINDINGS}

In regard to year in teacher preparation program, survey results showed that $2.9 \%$ participants were firstyear preservice teachers, $37.9 \%$ were second-year, $43.6 \%$ were third-year, $11.4 \%$ were fourth-year, and $4.3 \%$ needed extra time to complete their degree. In terms of major area of study, $40.4 \%$ of participants majored in early childhood, $15.4 \%$ in middle childhood, and $44.1 \%$ in Adolescent to Young Adult (AYA). Participants were asked about their online and blended learning experiences prior to the partnership experience. A vast majority of participants (97.2\%) had no experience of online or blended learning in their K-12 schools. However, slightly less than half of the participants $(45.4 \%)$ had taken a fully online course in college. When it comes to experiences of blended courses, $30.7 \%$ participants had taken a blended course (prior to the current course in which this study was conducted), and $69.3 \%$ did not have prior experience in blended learning environments. Participants reported little intent of teaching in a virtual K-12 school as their teacher preparation field experience. Most participants (79.4\%) reported that they would prefer face-to-face field experiences, $17.7 \%$ were interested in a combination of both, while only $2.8 \%$ reported an interest solely in virtual field experiences. 


\section{QUANTITATIVE ANALYSIS OF PERCEPTION PAPERS}

Participants' perceptions of K-12 online teaching and learning were compared before and after the partnership intervention using paired-sample t-tests. There was a significant difference in participants' perceptions on three dimensions, including the equivalency of learning online versus face-toface $[t(33)=2.51, \mathrm{p}<.05]$, developing positive relationships $[t(33)=3.62, \mathrm{p}<.00]$, and interactive learning $[t(33)=4.9, \mathrm{p}=.00]$. Another variable, the ideal age for online learning, was marginally significant $[t(33)=4.9, \mathrm{p}=.05]$.

\section{Table 3. Means and Standard Deviations of Coded Scores}

\begin{tabular}{|c|c|c|c|c|c|}
\hline \# & Variables & $\mathbf{N}$ & Mean & SD & $p$ \\
\hline Pair 1 & Choice of field experience & 34 & .000 & .550 & 1.00 \\
\hline Pair 2 & Ideal age of students to learn online & 34 & .529 & 1.522 & .05 \\
\hline Pair 3 & Equivalency of learning online versus face-to-face & 34 & .500 & 1.161 & .01 \\
\hline Pair 4 & Positive teacher-student relationships & 34 & .647 & 1.041 & .00 \\
\hline Pair 5 & Managing discipline & 34 & .235 & 1.103 & .22 \\
\hline Pair 6 & Individualized learning & 34 & .294 & 1.194 & .16 \\
\hline Pair 7 & Interactive learning & 34 & .912 & 1.111 & .00 \\
\hline
\end{tabular}

The data suggests that preservice teachers' perceptions in many aspects of online education changed significantly. Prior to the partnership, the majority of participants (28 out of 34) believed that there exists a major difference in these two types of instruction. The number dropped drastically (17 participants) as more participants recognized similarities and connections between online education and face-to-face education. Preservice teachers statements included, "online teaching can be equivalent to face-to-face teaching in various ways"; "it can be fun, interactive, student-centered, individualized"; and that it can "foster positive relationships among teachers and students".

The preservice teachers reported an improved perception on the possibility of creating positive relationships in online environments. While roughly half of the participants (16 out of 34) believed in the insurmountable difficulties in creating positive relationships, only five participants' perceptions remained unchanged after the intervention. One preservice teacher stated, "I believe students and teachers can build positive relationships in online classrooms because there is still an element of interaction. (i.e., Students still 'go' to class and hear the teacher, as well as email or twitter correspondence)." They also recognized that online classes allow the teacher to be more accessible to help the student and provide feedback. One participant stated, "I also have realized that having class through a webcam makes the instructor more readily available to the student. Even after class is over, if a student were to have a question, I think the likelihood of a speedy response from the instructor is quite high."

Preservice teachers reported an improved perception on the possibility of creating an interactive, student-centered experience in virtual settings. Prior to the intervention, 14 participants did not believe that learning experiences in online settings could be interactive and student-centered. Only one student remained unchanged. Preservice teachers were clearly convinced that online teachers could offer interactive learning through the videos they watched. One preservice teacher commented, "An online class can foster interactive learning and a student-centered classroom because the teacher can assign work that displays this and can get all the students involved." 


\section{QUALITATIVE ANALYSIS OF PERCEPTION PAPERS}

The 34 perception papers were coded qualitatively to determine participants' views of the benefits of online learning prior to and after exposure to the learning activities in this class. Overall, the data suggested that many preservice teachers held a much more positive view toward online teaching, while recognizing the challenges after experiencing the activities of the study. Preservice teachers often cited more than one benefit; therefore, the numbers below are higher than the total number of papers analyzed. In terms of perceptions of benefits of online learning, the most cited response was a flexible education (pre $n=14$; post $n=10$ ). According to preservice teacher's comments, the fact that online learning eliminates geographical and temporal barriers is one of the greatest appeals. Not being restricted by the physical brick and mortar boundaries can significantly free participants' time and enable them to learn much more otherwise. Other benefits reported included the ability for preservice teachers' to set their own pace (pre $n=12$; post $n=11$ ), the possibility of an individualized curriculum (pre $n=6$; post $n=7$ ), and the strength of learning in a bully-free environment (pre $n=4$; post $n=8$ ). Preservice teachers appreciated the appeal of self-paced learning that online learning affords and believed that online learning will "help students who have difficulty in classroom settings make more adequate accommodations." Participants also stressed that an online learning mode requires learners to be more self-disciplined and to be truly independent learners. It was noted, "Learning [means] to be responsible to do your work without a teacher being there to encourage you to keep working or to remind you to do an assignment". Some suggested that behavioral problems, such as bullying, are much less common in an online classroom.

Preservice teachers were asked to list the negative perceptions associated with K-12 online learning. Responses were analyzed before exposure to the learning activities as well as after. A lack of socialization was the most cited drawback (pre $n=20$; post $n=21$ ). Though they now realized how much technology could boost interactivity, almost all participants still believed that the level of interactivity in online classes is not equivalent to what learners experience in a face-to-face classroom. As one elaborated, "In person, the students can read the teacher's emotions and the students can feel by the way the teacher interacts with the students how positive their relationship really is. It is easier to trust someone you have met and you can talk to in person, rather that trusting someone you have never met face to face before."

Other frequently mentioned drawbacks were the difficulty in creating teacher-student connections (pre $n=14$; post $n=2$ ), a struggle to motivate students (pre $n=8$; post $n=7$ ), and lack of studentstudent collaboration (pre $n=4$; post $n=2$ ). Some participants also believed that it is easier to build teacher-student relationships in physical classrooms and true collaboration is more difficult to foster online. The types of collaborative work, such as online discussions, "are good substitute for class interaction, but it can never be the same [as face-to-face interaction]."

\section{FOCUS GROUPS}

The first theme is that the majority of focus group participants indicated that the videos were sufficient at providing a glimpse of synchronous, online teaching sessions. Ten out of 31 preservice teachers verbalized that the videos created a positive perception change regarding online education. No one felt that the videos created negative perceptional changes. One preservice teacher stated, "It was very helpful because I think a lot of us had no idea what it was going to be like, so anything was helpful to be able to picture it a little more." Another mentioned that the videos were "almost like sitting in a real classroom." Preservice teachers commented about being surprised at the high level of interaction between students. For example, one participant commented, "I went into thinking that [the online school] was kind of like, you throw out like a folder. I didn't really see them interacting, like with each other, until I watched the videos. I thought that was pretty cool."

The groups next discussed the guest presenters, who were current online K-12 teachers. The chorus from all three focus groups maintained that having guest presenters was a beneficial activity. The majority of participants commented that the presenters spoke freely, answered audience questions hon- 
estly, and gave them an appreciation for what being an online teacher is like. Other comments surrounding the guest presentations included, "It helped to understand what goes on in the classroom to hear the teachers speak." Preservice teachers felt that the presenters spoke not only about the positives of online teaching, but the negative aspects as well. A preservice teacher said:

I liked how our speakers didn't shy away from the negatives about this. One of our speakers was saying that it is hard to get that engagement with students. You talk to them on the phone a lot, you get to know them, but there's still that not being with them and seeing them and she said how if someone doesn't show up, you have no control. She was pointing out the negatives, but also talking about why she loves it.

The conversation shifted to online teaching in general. Students were asked, "Prior to this class, had you thought about teaching in a distance environment?" All 31 participants replied, "No." They were next asked if they would consider applying for a position that was fully online. Thirteen of the 31 participants said that they would consider it. Participants were then asked if they would consider applying for a position that utilized blended learning. (Participants were told that they could raise their hand for more than one option.) Seventeen of the participants indicated that teaching in a blended learning format would be an option. Eighteen participants raised their hands indicating that they would definitely prefer teaching in a traditional classroom.

The data also suggested after experiencing the online learning activities, preservice teachers were able to think through an alternative lens as if they were an online teacher and become more open to the idea of teaching online. Although the data above indicated that the majority of participants preferred employment in a traditional room, participants showed signs that they began to internalize teaching online and to think of themselves in a virtual setting. One preservice teacher, an early childhood major stated, "We're just always wondering, how does that work? How are the parents involved? What would this be like for a kindergartener or first grader?" Another responded, "And that's how I was thinking of it, from a special education view. How exactly does someone with special needs - like how are they evaluated? "

While teaching online may not be a first choice of employment, participants reported that the notion of online teaching was now an option and that they were open to the idea. A preservice teacher commented:

I like having the option, I feel, empowered, maybe that's not the right word, but I think it's very interesting and I like that we have talked about it because it's an interesting option to have later on. And I think I would like to always keep it in the back of my mind and maybe explore it. See what I can learn from it. I don't think it would be my first choice to do fully online, but there's something about it that makes me want to keep it in the back of my mind and to learn more about it. It's an interesting option.

Twenty-six participants indicated that they would be interested in a virtual field experience as they continued their teacher education, as long as the majority of their field experiences were in a traditional setting. Those who abstained commented that they do not see themselves teaching in an online school, or that they felt their technological skills were not up to par to be successful in an online environment.

\section{IMPLICATIONS}

The data suggests that, after exposure to online teaching and learning activities at the K-12 level, preservice teachers' perceptions of online schooling had changed. Preservice teachers started viewing traditional schooling and online schooling as being equivalent. Through both qualitative and quantitative data analyses, the undergraduates reported that positive student-teacher relationships were possible in an online environment. Positive perception changes also occurred regarding student-student relationships in online schools, namely that virtual schooling is a safe, yet still interactive, alternative. Important to the class's aim of exposing preservice teachers to online K-12 teaching and learning, 
these future teachers reported increased understanding and familiarity to this emerging form of schooling. From a situated cognition perspective, exposing preservice teachers to online K-12 teaching via observing online teaching classrooms in a video format helped them think through a different lens, developing their own meaning of online K-12 teaching that contributes to their further knowledge construction of online pedagogy.

Through focus group discussions, it appeared as if preservice teachers were viewing online education and traditional education as two polarized worlds, when in fact, all preservice teachers are likely going to need these skills for future careers. Preservice teachers felt as if it was either for them or not for them. To this, another classmate responded:

Well, my sister is a science teacher. She decided to switch her classroom to a flipped classroom. So everything is online, they get to watch videos online, do quizzes, and then when they come to class they do labs and stuff like that. And she said an online experience would have been very helpful. She's teaching face-to-face, but she's also teaching online. So I think that [this project] would definitely help if your district asked you to do something like this or you decided to try.

Because of the prevalence of the notion of online teaching being an all or nothing endeavor, subsequent sections of this course (during the 2014-2015 school year) added another component to the curriculum: a classroom discussion answering the question, "What might education look like in 2020? 2030?" Preservice teachers discussed how online education is likely to be a part of all their classrooms; traditional or otherwise.

Data from this study reaffirmed that preparing preservice teachers for online teaching requires a systematic approach that demands the successful implementation of online education and purposeful planning in an early stage (Picciano, 2015). Perception change took place as an initial step, but an updated design of curriculum and purposeful online learning activities needs to be closely integrated into teacher education programs in order to adequately prepare preservice teachers. Past research has suggested that teacher education programs sufficiently prepare preservice teachers in terms of pedagogy and content, but that graduating students lack skills in the integration of technology in their classrooms (Archambault, 2011). Online classrooms rely intently on technology integration, so it is imperative that future teachers are prepared to merge technology, content, and pedagogy, as described in the TPACK framework (Mishra \& Koehler, 2006).

Findings of this study suggested that merging content and pedagogy with technology integration should be a holistic endeavor, encompassing coursework from a variety of instructional methods and pedagogy-related courses, rather than relying solely on a stand-alone technology class (Archambault, 2011). In integrating online pedagogy in content classes (such as science methods, math methods, etc.), existing components of the classes can be explored in terms of teaching virtually. Preservice teachers need to be equipped with pedagogical, content, and technological knowledge and skills before they enter into clinical experience of online teaching and virtual field placements (Mishra \& Koehler, 2006).

\section{LIMITATIONS}

This study suggested that preservice teachers' perceptions of online teaching improved after exposure to online learning activities at the K-12 level, their understanding of online K-12 learning was heightened, and that they began to conceptualize themselves teaching in blended or online learning environments. The ignition for integrating these activities in a required technology in education course was to prepare preservice teachers to be successful in future virtual or blended field experiences. At the time of the study, these preservice teachers who participated in the study had not yet had the opportunity to experience virtual field experiences. The researchers acknowledge that the findings of the study could be further substantiated when comparing preservice teachers' actual virtual field experiences with those who had not participated in the introductory course prior to engag- 
Preparing Teacher Candidates for Virtual Field Placements

ing in virtual field experiences. The researchers also acknowledge that only a partial number of student papers were examined in this study, which makes it difficult to generalize these results to a larger population.

\section{FUTURE RESEARCH}

The goal of this exposure class was to provide preservice teachers with a foundation in online K-12 teaching and learning so that future virtual field experiences could commence. Ultimately, the researchers hope to understand if the exposure course, combined with a short-term clinical experiences and long-term online apprenticeships, may serve to prepare graduates with the skills necessary to teach in classrooms of the future.

\section{CONCLUSIONS}

The activities orienting preservice teachers to online K-12 teaching helped them with reconstructing a positive perception toward of K-12 online teaching. By and large, an exposure to online K-12 classrooms stimulated preservice teachers' interest in online teaching as they began to feel that online education could be equivalent to traditional education. Through the learning activities, preservice teachers discovered that positive teacher-to-student relationships could be fostered online. Learning from exemplar online K-12 synchronous teaching sessions and guest talks, preservice teachers reached a greater understanding of K-12 online learning, seeing tremendous potential for positive student-tostudent interactions and noted how a bully-free environment may be superior for some students. Not all preservice teachers were eager to teach online as their career aspiration but the preservice teachers reported that they have begun to picture themselves teaching online, and questioned the possibility more deeply. Of utmost importance, preservice teachers' familiarity with online and blended learning increased, setting a firm foundation for future virtual field experiences in full-time online schools or in schools utilizing a form of blended learning.

\section{REFERENCES}

Anderson, T., \& Shattuck, J. (2012). Design-based research A decade of progress in education research? Educational Researcher, 41(1), 16-25.

Archambault, L. (2011). The practitioner's perspective on teacher education: Preparing for the K-12 online classroom. Journal of Technology and Teacher Education, 19(1), 73-91.

Archambault, L., DeBruler, K., \& Freidhoff, J. (2014). K-12 Online and blended teacher licensure: Striking a balance between policy and preparedness. Journal of Technology and Teacher Education, 22(1), 83-106.

Barbour, M. K., Siko, J., Gross, E., \& Waddell, K. (2013). Virtually unprepared: Examining the preparation of K-12 online teachers. In R. Hartshorne, T. L. Heafner, \& T. Petty (Eds.), Teacher education programs and online learning tools: Innovations in teacher preparation (pp. 60-81). IGI Global

Brecheisen, K M. (2015). Preparing K-12 teachers for online instruction. Retrieved from https://etd.ohiolink.edu/!etd.send file?accession=ashland1449060061\&disposition=inline

Brown, J. S., Collins, A., \& Duguid, P. (1989). Situated cognition and the culture of learning. Educational Researcher, 18(1), 32-41.

Clark, T., \& Barbour, M. (2015). Online, blended, and distance education in schools: Building successful programs. Sterling, VA: Stylus Publishing.

Compton, L. K. L., Davis, N., \& Mackey, J. (2009). Field experience in virtual schools--To be there virtually. Journal of Technology and Teacher Education, 17(4), 459-477.

Council for the Accreditation of Educator Preparation. (2015, September). Standard 2: Clinical partnership and practice. Retrieved from http://caepnet.org/standards/standard-2

Creswell, J. W., \& Clark, V. L. P. (2007). Designing and conducting mixed methods research. SAGE Publications. 
Davis, N. E., \& Roblyer, M. D. (2005). Preparing teachers for the "schools that technology built": Evaluation of a program to train teachers for virtual schooling. Journal of Research on Technology in Education, 37(4), 399409.

DeNisco, A. (2013). Preparing for online teaching: Web-based assessment and communication skills in K-12. District Administration, 49(5), 38-41.

Denzin, N. K., \& Lincoln, Y. S. (2008). Collecting and interpreting qualitative materials (Vol. 3). Thousand Oaks, CA: Sage Publications.

Kennedy, K., \& Archambault, L. (2012a). Design and development of field experiences in K-12 online learning environments. The Journal of Applied Instructional Design, 2(1), 35-49.

Kennedy, K., \& Archambault, L. (2012b). Offering preservice teachers field experiences in K-12 online learning: A national survey of teacher education programs. Journal of Teacher Education, 63(3), 185-200.

Mishra, P., \& Koehler, M. J. (2006). Technological pedagogical content knowledge: A framework for teacher knowledge. Teachers College Record, 108(6), 1017-1054.

Patrick, S., \& Sturgis, C. (2015). Maximizing competency education and blended learning: Insights from experts. Vienna, VA: iNACOL (International Association for K-12 Online Learning); Competency Works.

Picciano, A. (2015). Planning for online education: A systems model. Online Learning, 19(5). Retrieved from http://olj.onlinelearningconsortium.org/index.php/olj/article/view/548/187

Patton, M. Q. (2002). Qualitative research and evaluation methods. Thousand Oaks, CA: Sage Publications.

Powell, A., Rabbitt, B., \& Kennedy, K. (2014). iNACOL blended learning teacher competency framework. Vienna, VA: iNACOL (International Association for K-12 Online Learning).

Pourreau, L. (2015). Interview with Joe Freidhoff: A bird's eye view of K-12 online learning. Online Learning, 19(5). Retrieved from http://olj.onlinelearningconsortium.org/index.php/olj/article/view/746/177

Saldaña, J. (2013). The coding manual for qualitative researchers. Thousand Oaks, CA: Sage Publications.

Stemler, S. (2001). An overview of content analysis. Practical Assessment, Research \& Evaluation, 7(17). Retrieved from http:/ PAREonline.net/getvn.asp? $\mathrm{v}=7 \& \mathrm{n}=17$

Watson, J., Pape, L., Murin, A., Gemin, B., \& Vashaw, L. (2014). Keeping pace with K-12 digital learning 2014. Evergreen, CO: Evergreen Education Group.

Wilkens, C., Eckdahl, K., Monroe, M., Cook, V., Giblin, T., \& Coon, J. (2014). Communication, community, and disconnection: Pre-service teachers in virtual school field experiences. Journal of Educational Technology Systems, 43(2), 143-157.

\section{BIOGRAPHIES}

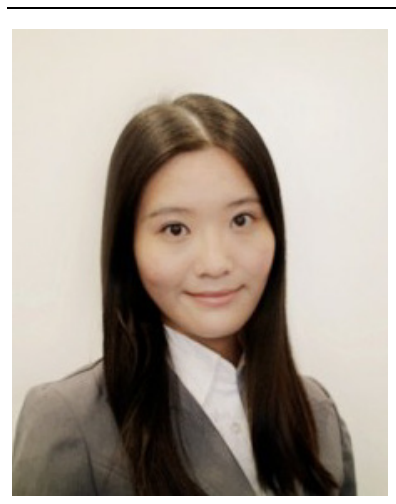

Dr. Tian Luo is an assistant professor in the Instructional Design \& Technology program at Old Dominion University. She received her degree in Instructional Technology from Ohio University in 2014. Formerly, she had worked as an instructional design professional in both higher education and corporate settings. Her research interests center on using social media to facilitate student learning in both formal and informal contexts, and designing collaborative and authentic learning environments supported and enhanced by emerging technologies. Her work has been published in peer-reviewed journals, such as, British Journal of Educational Technology, and Journal of Computing in Higher Education. 


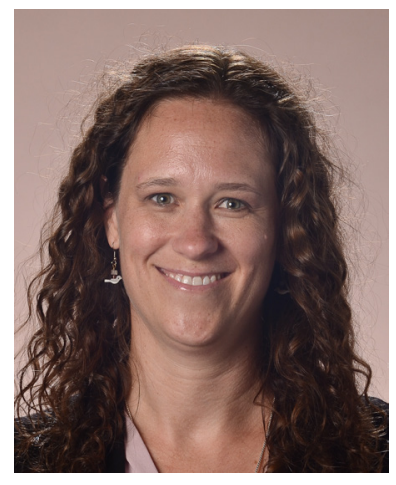

Dr. Laura Hibbard is currently in her eleventh year teaching fifth grade at an online, public K-12 school. Prior to working in a full-time online school, Dr. Hibbard taught for four years in a traditional school. Dr. Hibbard holds a doctorate in Instructional Technology from Ohio University. Her dissertation focused on online students' access to literature and examined the roles of both physical book libraries and ebook libraries in online schools. Her research interests include online K-12 learning with a focus on student literacy and student-centered instruction as well as exposing teacher candidates to online K-12 teaching and learning. Dr. Hibbard teaches part time in Ohio University's Instructional Technology department.

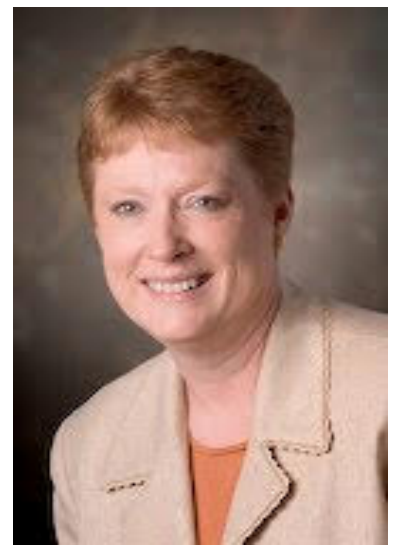

Dr. Teresa Franklin, Professor Emerita, Educational Studies - Instructional Technology and former Director of the Office of Global Affairs OHIO Group, has a passion for teaching and learning through the integration of technology into curriculum and instruction that spans forty years. She was a recipient of the 2014 iNACOL Innovation Award for outstanding research in blended learning. She is an evaluator for CAEP (National Council for the Accreditation of Teacher Education) and the Fulbright Scholars program. Research interests include program evaluation, evaluation of online/e-learning environments, and technology integration and development. Dr. Franklin has significant journal publications and textbooks that integrate technology into science and math including Teaching Science for All Children (5 editions), Virtual Games and Career Exploration and The Mobile School: Digital communities created by mobile learners; Second Life Learners: An exploration of teaching and learning in a virtual environment and The Changing Roles of Faculty and Students when Mobile Devices Enter the Higher Education Classroom. She is a sought after keynote speaker both nationally (Spelman College, SITE, OHIO eTech) and internationally (Turkey, France, Spain, Jordan, Japan, and Saudi Arabia) concerning professional development in the use of assessments and technology to improve teaching and learning.

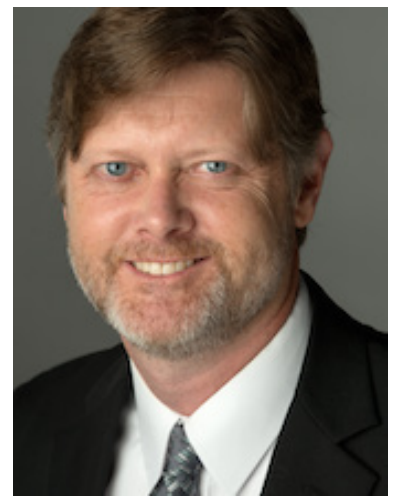

David Richard Moore received a Ph.D. in Instructional Systems Design from Virginia Polytechnic Institute and State University (Virginia Tech) in 1995. His research focuses on Instructional Design with particular focus on tools, techniques, and strategies for task analysis. Much of this research is conducted through specially designed computer-based interactive systems. David is Professor of Instructional Technology and serves as the Secretary to the Board of Trustees at Ohio University. 